(it)

\title{
Effect of Feed Combination of Avocado (Persea americana M.) and Pumpkin Seed (Cucurbita moschata Duch.) on Villi Height and Goblet Cell Number of Goblet Fish (Osphronemus gourami Lac.)
}

\author{
Halimatussakdiah ${ }^{1}$, Safrida $^{1^{*}}$, Muhibbuddin ${ }^{1}$ \\ ${ }^{1}$ Biology Education, Faculty of Teacher Training, Syiah Kuala University, Banda Aceh, Indonesia.
}

DOI: $10.29303 /$ jppipa.v7i4.802

\section{Article Info}

Received : July $7^{\text {th }}, 2021$

Revised : September $7^{\text {th }}, 2021$

Accepted: October 10th, 2021

\begin{abstract}
In Indonesia, there are several types of freshwater fish that the community has cultivated. Besides having high nutritional value, Freshwater fish also have high economic value for trading, such as gourami. One of the obstacles in the cultivation of freshwater fish is the price of feed. This research is oriented towards alternative feeds to reduce production costs by utilizing avocado seeds and pumpkin seeds. This study aimed to determine the effect of feeding a combination of avocado seeds and pumpkin seeds on the histopathology of gourami. This study used a non-factorial completely randomized design (CRD) method with four treatments and six replications P0, P1, P2, and P3. P0 (Control feed/pellet), P1 (Feed 40 grams of avocado seeds +40 grams of pumpkin seeds +20 grams of mixed ingredients), P2 (Feed of 20 grams of avocado seeds +60 grams of pumpkin seeds +20 grams of mixed ingredients) and P3 (Feed 60 grams of avocado seeds +20 grams of pumpkin seeds +20 grams of mixed ingredients). Data were analyzed using ANOVA and Advanced Test with a significant level of $5 \%$. The results showed that the P2 treatment could increase the villi height and the number of Goblet cells in the intestines of gourami fish. It can be concluded that the combination of avocado seeds and pumpkin seeds has a significant effect on the histopathological picture of the digestive organs of gourami.
\end{abstract}

Keywords: Freshwater fish; feed; histopathology; villi height; goblet cell count

Citation: Halimatussakdiah, H., Safrida, S., \& Muhibbuddin, M. (2021). Effect of Feed Combination of Avocado (Persea americana M.) and Pumpkin Seed (Cucurbita moschata Duch.) on Villi Height and Goblet Cell Number of Goblet Fish (Osphronemus gourami Lac.). Jurnal Penelitian Pendidikan IPA, 7(4), 669-675. doi:https://doi.org/10.29303/jppipa.v7i4.802

\section{Introduction}

In Indonesia, there are several types of freshwater fish that the community has cultivated. Besides having high nutritional value, freshwater fish also have high economic value for trading, such as gourami (Osphronemus gourami Lac.) (Amri, 2007).

One of the factors that determine the success of fish farming is the availability of feed. Feeding fish is not enough to rely on natural food, so it is necessary to add artificial feed. Currently, it is estimated that the need for feed for freshwater fish farming from year to year continues to increase. In 2018, the need for feed was around 9,667,620 tons. In 2019 it was estimated to reach $10,800,960$ tons. Thus, KKP urges the public to increase their independent feed business, but the raw materials used are expensive because they rely on imported raw materials. As a result, the selling price of feed continues to increase to Rp. 7000 per $\mathrm{kg}$ (KKP, 2019).

To increase production, one of the important aspects that must be considered in aquaculture activities is the selection of the right feed because feed is a source 
of energy that plays a role in improving fish quality. The amount of feed needed in a fish farming business can reach $70 \%$ of the total production cost, so the Ministry of Maritime Affairs and Fisheries is trying to increase independent feed businesses to reduce production costs for fish cultivators. Good feed is feed that is suitable for the needs of the fish species being cultivated. Appropriate feeding also supports the histopathological development of healthy digestive organs.

The utilization of feed from natural ingredients that have a low price is expected to be a breakthrough and alternative to reduce production costs. One way to minimize feed costs is the selection of local feed ingredients. Based on these results, researchers will make fish feed to reduce production costs by utilizing avocado seeds and pumpkin seeds. Avocado seeds and pumpkin seeds are waste that can be used because avocado seeds contain 4.95 grams of protein (Muin et al., 2014), while pumpkin seeds contain 30.6 grams of protein (Perdanianti and Arum, 2009). In principle, the manufacture of fish feed is the use of natural resources that are not suitable for direct human consumption or the utilization of seeds leftover from making juice that is not used but has a nutritional value and economic value that is smaller than the animal food that will be produced.

Feed is also the most important element in supporting the growth and survival of fish. According to Wahyuningsih (2009), the types of commercially cultured fish are reared semi-intensively. The feed that is eaten completely relies on the supply provided by the cultivators, while fish that are kept traditionally or fish that live freely in nature only use feed that is available naturally experience. That's why the growth rate and survival rate of fish kept intensively, and semiintensively are much higher than fish kept traditionally or free-living in nature.

Feeding a combination of avocado seeds and pumpkin seeds to gourami will be monitored for clinical symptoms. The examination was carried out mainly by observing the anatomical, pathological lesions of the digestive organs of the fish. The examination was carried out by taking a sample of the intestine and observing it using a microscope.

Histopathological examination is a supporter of a diagnosis and can be the main diagnostic examination of disease by finding pathognomonic cell or tissue changes due to a particular disease. This is because clinical symptoms and anatomical, pathological lesions that occur in the digestive organs of fish are often caused by the type of feed consumed by the fish. Healthy fish are fish that are free from disease and chemicals. The characteristics of healthy fish are slightly slimy skin, good reflexes, agile body movements, bright fish colors, and a flat stomach (Safrida, 2020).
The condition of fish that are susceptible to disease will reduce productivity, so that feed is needed that meets nutritional needs and can also improve the health status of fish. Thus, it is necessary to carry out a histopathological examination of the digestive organs and the degree of fish health further to determine the picture of fish health by using a combination of avocado seeds and pumpkin seeds on gourami fish.

\section{Method}

This study used an experimental method with a non-factorial RAL research design with four treatments and six replications. The approach used in this research is quantitative. This research was conducted in Keumuneng Peut Village, Darul Aman District, East Aceh Regency, at the Agricultural Laboratory and at the Laboratory of the Faculty of Veterinary Medicine Unsyiah from September to December 2020. The research object used was 96 tails of 1-month-old gourami fish and sized 5-6.8 cm manifold. Male sex. Fish data collection was carried out for two months with 60 days of treatment.

Histopathological sampling was carried out once at the end of the treatment. Fish samples were brought to the Laboratory of the Faculty of Veterinary Medicine. Histopathology was measured by observing, studying, and examining the intestinal organ tissue of the fish. The fish was dissected, and the small intestine was taken. The micro technical process is carried out by preparing specimens of all fish's small intestine tissue. The small intestine is stretched, and the duodenum is cut. The duodenum is cleaned of fat and food residues in the small intestine using $0.9 \%$ physiological $\mathrm{NaCl}$. This examination is performed on abnormal changes at the tissue level of the organ. Histopathological preparations include Fixation, Dehydration, Embedding, Sectioning, laying on glass objects, Afixxing, Mounting, and Labeling. For each treatment, one test fish was taken as a fish sample, dissected, and the intestines were taken, then the villi height and the number of intestinal goblet cells were measured.

\section{Result and Discussion}

Research that has been carried out for 60 days in each treatment has a different histopathological picture of the intestine. The difference in each treatment was seen from the comparison of villi height and the number of Goblet cells in the intestines of gourami fish. 

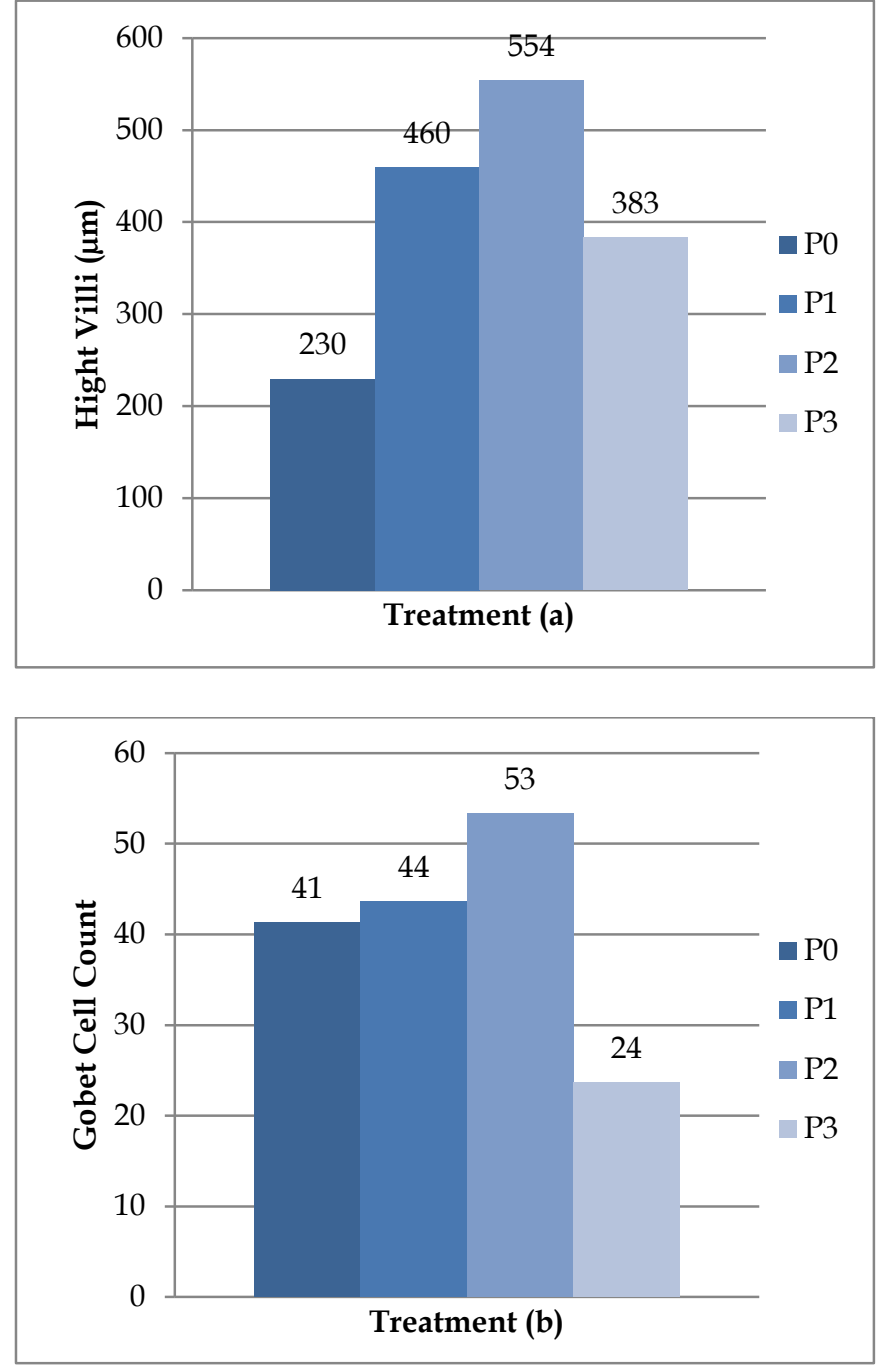

Figure 1. Average Intestinal Histopathology Comparison Gourami After 60 Days, (a) Villi Heigh and (b) Number of Goblet Cells

Based on Figure 1, the average ratio of villi height and the number of goblet cells in the intestines of gourami for 60 days. In the figure, it is known that P2 is the treatment with the highest average value of villi height and P2 is the treatment with the highest average value of the number of goblet cells. While the lowest mean value of villi height was found in treatment P0, and the lowest average value of the number of goblet cells was found in treatment $\mathrm{P} 3$. The average value to the ratio of the height of the gourami intestinal villi was then analyzed using statistical tests to obtain F-count (125.445) $>$ F-table (3.098) with a significant level of 0.05. This means that feeding avocado seeds and pumpkin seeds has a significant effect on the height of gourami villi. Histopathological description of villous height can be seen in Figure 2.

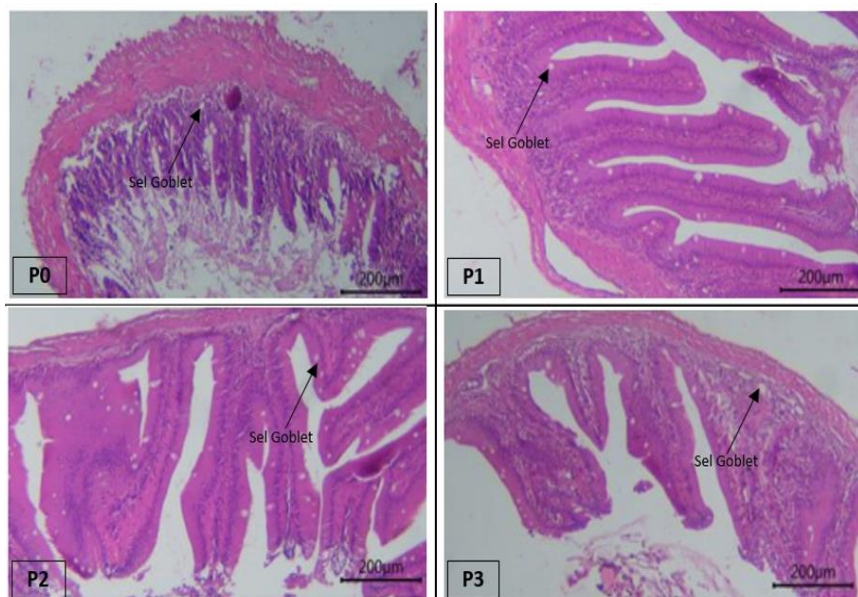

Figure 2. Height of Gourami Fish Intestine Villi

Based on the ANOVA test, the coefficient of diversity was $7.367 \%$. The data was further tested with the BNT follow-up test (Reverse Significant Difference). The results of the BNT test are presented in Table 1.

Table 1. Average Height of Gourami Villi (BNT 0.05)

\begin{tabular}{llll}
\hline No & Treatment & Average $(\mu \mathrm{m})$ & BNT 0.05 \\
\hline 1 & P0 & $229.63 \pm 6.47$ & $\mathrm{a}$ \\
2 & P1 & $459.81 \pm 25.67$ & $\mathrm{C}$ \\
3 & P2 & $553.52 \pm 30.17$ & $\mathrm{~d}$ \\
4 & P3 & $383.33 \pm 37.13$ & $\mathrm{~b}$ \\
\hline
\end{tabular}

Based on the results of statistical tests on the number of goblet cells of goblet fish, the F-count value (28.794) > F-table (3.098) with a significant level of 0.05 was obtained. This means that the feeding of avocado seeds and pumpkin seeds significantly affects the number of Goblet Cells. The Goblet Cells of the gourami fish can be seen in Figure 3.

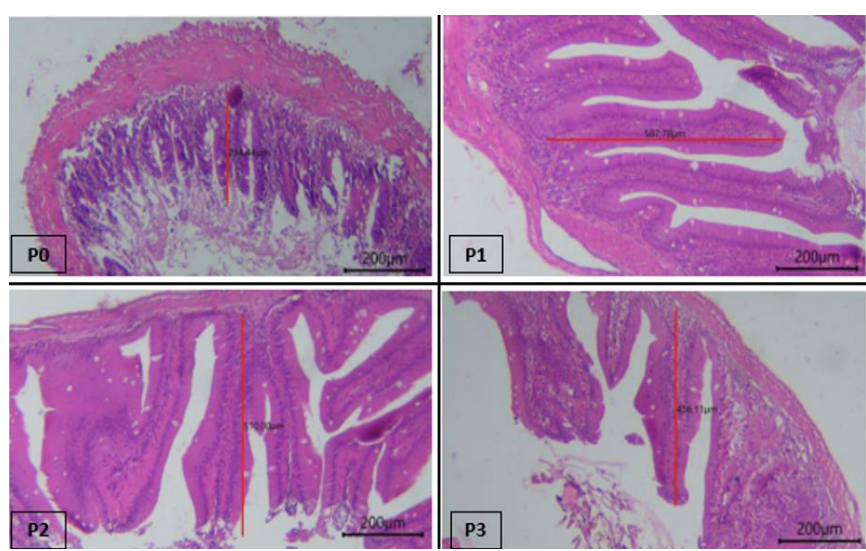

Figure 3. Goblet cells in the intestines of gourami fish

From the ANOVA test, the coefficient of diversity is $13.938 \%$. To find out the difference between treatments, the data were further tested with the DMRT (Duncan) follow-up test. Duncan's test results are presented in Table 2. 
Table 2. Average Goblet Cell Number of Goblet Fish

\begin{tabular}{llll}
\hline No & Treantment & Average $($ per $200 \mu \mathrm{m})$ & Duncan 0.05 \\
\hline 1 & P0 & $41.33 \pm 1.37$ & $\mathrm{ab}$ \\
2 & P1 & $43.67 \pm 2.56$ & $\mathrm{bc}$ \\
3 & P2 & $53.33 \pm 9.80$ & $\mathrm{bc}$ \\
4 & P3 & $23.67 \pm 1.24$ & $\mathrm{a}$ \\
\hline
\end{tabular}

Based on the results of the ANOVA test and the Advanced BNT and Duncan tests as shown in Tables 1 and 2, the treatment significantly affected the villi height and the number of Goblet cells produced for 60 days after feeding with a mixture of avocado and pumpkin seeds for gourami. From the results above, it can be seen that P2 is the treatment that gives the most optimal results for gourami. Feeding a combination of avocado seeds and pumpkin seeds in the treatment significantly affected the villi height and the number of goblet cells of goblet carp that had been reared for 60 days of treatment.

Based on Figures 1, 2, and 3, the maximum villi height and the number of Goblet Cells were found in P2 with a feeding concentration of 20 grams of avocado seed flour +60 grams of pumpkin seed flour +20 grams of mixed material. The results of the research data obtained after 60 days in each treatment showed that the average height of the villi in the treatment $\mathrm{P} 0$ and $\mathrm{P} 2$ of Gouramy Fish was $229.63 \mathrm{~m}$ and $553.52 \mathrm{~m}$, while the number of Goblet cells P0 and P2 of Goblet Fish was 41.33 (per $200 \mathrm{~m}$ ) and 53.33 (per $200 \mathrm{~m}$ ). It is better to use P2 treatment, which contains $6.91 \%$ crude fiber, $18.94 \%$ fat, $25.01 \%$ crude protein, $3.75 \%$ ash, $8 \%$ water, $92 \%$ dry matter, is the most appropriate for gourami because the compound containing contained in the feed, can stimulate the digestive system in the fish body properly. This combination of feed is very suitable for increasing the number of Goblet cells produced by the intestinal glands of fish and can carry out the digestive process properly and produce maximum villi height.

This is in accordance with the research of Andini et al. (2017), which explains that there is a variety of incoming food, providing stimulation to epithelial cells and Goblet cells to respond to the type and consistency of the incoming food. The increasing number of Goblet cells is thought to be an adaptation of the intestinal epithelium in helping the digestive process in that part of the intestine. Goblet cells that increase in number help the digestive process of the type of food eaten and the type of environment in which the fish live (Purbomartono et al., 2004).

The types of cells commonly found in the intestines are enterocytes and goblet cells. Enterocyte cells have a vertical cylindrical (stem) shape and are only composed of a single layer of cells and play a role in the absorption of food while Goblet cells are shaped like a goblet, contain mucin which functions to lubricate food, provide protection in the walls and upper part of the intestine, as well as a defense medium against infection. parasite. Goblet cells secrete mucus to lubricate and protect the intestinal surface (Zainuddin et al., 2016). Goblet cells protect the upper part of the small intestine from pathogens and limit the movement and attachment of pathogens. Goblet cells synthesize and secrete mucus glycoproteins in the form of a gel to protect intestinal epithelial cells (Deplancke and Gaskins, 2001). The Liberkuhn glands also produce mucus in the intestinal mucosal lining (Rogers, 2002).

Intestinal glands (Liberkuhn glands) open to crypts in the intestinal villi. These glands form mucus and several enzymes for the metabolism of peptides, fats, carbohydrates, and intestinal sap (mucin), which functions to protect the intestinal mucosa (Aughey and Frye, 2001). The increase in mucin production is related to the number of intestinal glands and Goblet cells (Rogers, 2002). The intestinal mucosa contains many microorganisms, both commensal and pathogenic, which are capable of carrying out metabolism similar to carbohydrate fermentation. Pathogenic microorganisms (bacteria, viruses, and parasites) are able to inhibit the intestinal mucosa causing disease as a result of impaired productivity (Korkmaz and Kum, 2016). The primary components that protect the mucosal lining of the small intestine are the Goblet cells and the Liberkuhn glands that produce mucus continuously.

Teraoka (2000) states that the mucus layer found in the digestive tract of fish is useful for protection from the secretion of gastric acid $(\mathrm{HCl})$ produced by the stomach and then carried to the intestine. Mucus is able to neutralize $\mathrm{HCl}$ because it contains alkaline bicarbonate (Sharps, 1982). According to Dellman and Brown (1992), meat-eating fish and plants' digestive activity requires enzyme secretion. The secretion of this enzyme causes the intestine to stimulate Goblet cells to produce more mucus to protect the outer layer of the intestine against damage and irritation (Ingram, 1980).

The intestines of Tilapia can also function as digestive glands. One of the organs that function in the process of digestion and absorption of nutrients in the intestine. The best nutrient absorption process is found in the proximal intestine, which has villi height, villi width, and many villi, which can be associated with increased absorption of nutrients into the intestine blood flow (Ikpegbu et al., 2014). The wider the surface area of the intestinal villi, the greater the chance of absorption from the digestive tract (Erian et al., 2018). The response to the low efficiency of digestion in fish is shown by increasing the length of the intestine in order to maximize the assimilation of the breakdown of nutrients in the fish food. By expanding the digestive tract area (such as increasing the diameter of the digestive tract, increasing the length of the villi and microvilli or 
increasing the digestive tract), fish can maintain normal nutritional requirements (Rust, 2000).

The addition of a combination of avocado seeds and pumpkin seeds in the feed also had an impact on changes in the intestinal morphology of Tilapia, Carp, and Gourami fish. This shows that the balance of the number of combinations of ingredients given to the feed, the fish that consume the feed will produce longer intestines and villi (positive correlation). The increase in the height of the intestinal villi, especially in the P2 treatment, is thought to cause an increase in the nutrients absorbed by the intestine so that the body obtains more nutrients, which has an impact on digestion. In addition, the longer the villi are in the intestine, the greater the cross-sectional area of the villi so that the absorption of nutrients is maximized.

Intestinal performance is closely related to the growth of carp. The intestines of herbivorous fish tend to secrete enzymes that can accelerate the hydrolysis reaction of carbohydrates and fats, such as lipase and maltase. The results of the study of Poleksić et al. (2007) proved that the substitution of soy flour by $30 \%$ in carp feed can increase the length of the intestinal villi and the number of enterocytes. Enterocytes are cells whose upper surface leads to the intestinal cavity. These cells are the most dominant cells, the number of which will increase towards the back of the intestine. Enterocyte cells have small protrusions or small microvilli that act as food absorption (Fujaya, 2004).

The number and height of intestinal villi decrease towards the rectum, while Goblet cells increase in number (Petrinec et al., 2005). The high mucosal folds in the foregut are an adaptation to increase the surface area for nutrient absorption and also reduce the flow rate of food, so that ideal absorption can occur (Ikpegbu et al., 2014). Reduced mucosal folds towards the rectum and increased number of Goblet cells are associated with the assimilation of ions and fluids, lubricates and protects the intestinal mucosa from mechanical damage, and facilitates the expulsion of feces. Goblet cells produce mucus, which protects the intestinal mucosa from mechanical and chemical damage, assists the absorption and transport of molecules through the membrane, and protects against microorganisms (Arman and Ucuncu, 2017). According to Buddington et al. (1997), the intestine also regulates water and electrolyte balance and immunity.

According to Dellmaann et al. (1992), villi height varies depending on the area and species. This is in accordance with the function of the intestine in the opinion of Mumford et al. (2007), which states that the anterior part of the intestine functions to 1) transport food materials from the stomach to the posterior intestine, 2) for complete digestion by secreting enzymes from the walls and accessory glands, 3 ) to absorb the end products of digestion into the blood and lymph vessels. In its walls, and 4) to secrete certain hormones (namely Secretin, which stimulates pancreatic secretion).

The functions of the posterior intestine include absorption of fluid, mucus secretions (more Goblet cells), and some digestion which is accomplished by enzymes present in foodstuffs and excretion. The villi in each part of the intestine are seen separately. The length can influence the surface area of the intestinal villi, width, weight gain, the increase in the size of the cavity in the intestine, and the food consumed. This is in accordance with the opinion (Khojasteh et al., 2009), which states that the shape of the villi in each part of the intestine is different. The number and height of the intestinal villi decrease towards the posterior intestine, while the number of Goblet cells increases. The occurrence of sticking of two or more of the villi, the villi should be separated from each other, will inhibit the process of absorption of food.

According to the research results of Ikpegbu et al. (2014), the villi's size affects the process of nutrient absorption. High intestinal villi in the proximal part are associated with faster absorption of nutrients than short villi. The presence of villi is one way to increase the surface area for the absorption of nutrients and reduce the flow rate of food, so that ideal absorption can occur. The decrease in intestinal villi towards the rectum and an increase in the number of Goblet cells are associated with the assimilation of ions and fluids to lubricate and protect the intestinal mucosa from mechanical damage and assist facilitate the expulsion of feces (Erian et al., 2018).

Based on the results of research that has been carried out on gourami fish, it shows that the combination of avocado seeds and pumpkin seeds in treatment P2 with a feed concentration of 20 grams of avocado seed flour +60 grams of pumpkin seed flour + 20 grams of mixed ingredients, villi height and a number of goblet cells showed more optimal results than P0, P1, and P3.

\section{Conclusion}

Based on the discussion that has been described, it can be concluded that the combination of avocado seeds and pumpkin seeds had a significant effect on the villi height and the number of goblet cells in the intestines of gourami fish.

\section{Acknowledgments}

Alhamdulillah, thanks to the infinite, the writer prays to Allah SWT, who has bestowed His grace and guidance. Thanks to parents, husbands, and children who have provided support in completing this research. Thanks to 
the Agricultural Laboratory and at the Laboratory of the Faculty of Veterinary Medicine Unsyiah.

\section{References}

Amri., \& Khairuman. (2003). Budidaya Ikan Nila Secara Intensif: Jakarta: Agromedia Pustaka. [Indonesian]

Andini, D., Zainuddin, M. Jalaluddin, Fitriani, U. Balqis, N. Asmilia, \& Hamdan. (2017). Sebaran Sel Goblet pada Usus Lele Lokal (Clarias batrachus). Jimvet, 1(3):

299-304. doi:https://doi.org/10.21157/jim\%20vet..v1i3.32 95 [Indonesian]

Arman, S., \& İsisag Ucuncu, S. (2017). Histochemical characterization of convict cichlid (Amatitlania nigrofasciata) intestinal goblet cells. Pakistan Journal of Zoology, 49, 445-453. https://doi.org/10.17582/journal.pjz/2017.49.2. $\underline{445.453}$.

Aughey, E., \& Frye, F.L. (2001). Comparative Veterinary Histology. London: Manson Publishing/The Veterinary Press. Jakarta: Badan Standardisasi Nasional (BSN).

Buddington, R. K., Krogdahl, A., \& Bakke-Mckellep, A. M. (1997). The intestines of carnivorous fish: structure and functions and the relations with diet. Acta physiologica Scandinavica. Supplementum, 638, 67-80. Retrieved from: https://pubmed.ncbi.nlm.nih.gov/9421581/

Dellman, H.D., \& Brown, E. (1992). Histologi Veteriner Ed. III. Jakarta: UI Press.

Deplancke, B., \& Gaskins, H. R. (2001). Microbial modulation of innate defense: goblet cells and the intestinal mucus layer. The American journal of clinical nutrition, 73(6), 1131S-1141S. https://doi.org/10.1093/ajcn/73.6.1131S.

Erian, V., Zainuddin, Z., \& Balqis, U. (2018). Gambaran Luas Permukaan Vili Usus Ikan Lele Lokal (Clarias batrachus) Jantan Dewasa. Jurnal Ilmiah Mahasiswa Veteriner, 2(3): 283-287. doi:https://doi.org/10.21157/jim\%20vet..v2i3.78 34 [Indonesian]

Fujaya, Y. (2004). Fisiologi Ikan Dasar Pengembangan Teknik Perikanan. Yogyakarta: Rineka Cipta. [Indonesian]

Ikpegbu, E., Nlebedum, U.C., \& Ibe, C.S. (2014). The histology and mucin histochemistry of the farmed juvenile african catfish digestive tract (Clarias gariepinus B). Studia Universitatis "Vasile Goldis", Seria Stiintele Vietii, 24(1): 125-131.

Ingram, G.A. (1980). Natural immunity in fish. J. Fish Biology, 16: 46-60.

Khojasteh, S.M.B., Sheikhzadeh, F., Mohammadnejad, D., \& Azami, A. (2009). Histological, histochemical and ultrastructural study of the intestine of rainbow trout (Oncorhynchus mykiss). World Applied Sciences Journal, 6(11): 1525-1531. Retrieved from: https://www.cabdirect.org/cabdirect/abstract/ 20093251785

Korkmaz, D., \& Kum, S. (2016). A histological and histochemical study of the small intestine of the dromedary camel (Camelus dromedarius). Journal of Camel Practice and Research, 23(1). 111-116. doi : $\underline{10.5958 / 2277-8934.2016 .00018 .7}$

Muin, R.; Lestari, D., \& Wulan, T.S. (2014). Pengaruh Konsentrasi Asam Sulfat dan Waktu Fermentasi Terhadap Kadar Bioetanol yang Dihasilkan dari Biji Alpukat. Jurnal Teknik Kimia, 4(20). 1-7. Retrieved from: http://jtk.unsri.ac.id/index.php/jtk/article/vie $\underline{\mathrm{w} / 190}$ [Indonesian]

Mumford, S., Heidel, J., Smith, C., Morrison, J., Macconnell, B. and Blazer, V. (2007) Fish Histology and Histopathology. 4th Edition, US Fish \& Wildlife Service, West Virginia.

Perdanianti, A. M. \& Arum, Y. (2006). Ekstraksi dan Pengeringan Waluh untuk Mendapatkan Produk Fine Powder. Seminar Tugas Akhir S1 Teknik Kimia UNDIP 2009. Semarang: Universitas Diponegoro. [Indonesian]

Petrinec, Z., Nejedli, S., kužir, snježana, \& Opačak, A. (2005). Mucosubstances of the digestive tract mucosa in northern pike (Esox lucius L.) and European catfish (Silurus glanis L.). Veterinarski Arhiv, 75, 317-327.

Poleksić V, Rasković, B., Marković, Z., Dulić, Z., Stanković, M., Zivić, I., \& Lakić, N. (2007). Effects of different dietary protein sources on intestine and liver morphology of carp yearlings. Proceedings of the 3rd Serbian Congress for Microscopy. Belgrade, Serbia, Serbian Microscopy Society, 56(1): 237-238.

Purbomartono, C., Susatyo, P., \& Setiawan, A. (2004). Pola Penyebaran Sel Mukus Pada Saluran Pencernaan Ikan Tawes (Punctius javanicus). Jurnal Perikanan Universitas Gadjah Mada, 6(2), 6265. doi: http://dx.doi.org/10.22146/jfs.9046. [Indonesian]

Rogers, D.F. (2003). The airway goblet cell. The International Journal of Biochemistry \& Cell Biology, 35(1), $\quad 1-6$. https://doi.org/https://doi.org/10.1016/S13572725(02)00083-3.

Rust, M.B. (2000). Nutritional Physiology 3th ed. Amsterdam: Academis press.

Safrida, S., Noviasyah, N., \& Khairil, K. (2020). Effects of Moringa oleifera Leaves Powder in Fish Feed Toward Growth Rate and Health of Colossoma 
macropomum. Biosaintifika: Journal of Biology $\mathcal{E}$ Biology Education, 12(2), 186-191. doi:https://doi.org/10.15294/biosaintifika.v12i2. 22655.

Sharp, J. (1982). Cells, Organs, and Animals: An Approach To The Basic Medical Sciences. London: Blackwell Scientific Publication.

Teraoka, H. (2000). $\mathrm{Ca}^{2+}$ signaling in porcine duodenal glands by muscarinic receptor activation. Retrieved from: http://ajpgi.physiology.org/cgi/content/full/2 $\underline{80 / 4 / G 729}$

Wahyuningsih S. (2009). Pengaruh komposisi pakan terhadap laju pertumbuhan ikan Nila. Skripsi. Semarang: Fakultas Pendidikan Matematika dan Ilmu Pengetahuan Alam IKIP PGRI Semarang. [Indonesian]

Zainuddin, Z., Masyita, D., Sarayulis, S., Jalaluddin, M., Rahmi, E., \& Nasution, I. (2016). Gambaran Histologi Kelenjar Intestinal pada Duodenum Ayam Kampung (Gallus domesticus), Merpati (Columba domesticus) dan Bebek (Anser anser domesticus). Jurnal Medika Veterinaria, 10(1): 9-11. doi:https://doi.org/10.21157/j.med.vet..v10i1.40 $\underline{28}$ [Indonesian] 